\title{
África no Brasil: mapa de uma área em expansão
}

Beatriz Gallotti Mamigonian

Pouco se conhece sobre a experiência dos homens, mulheres e crianças das diferentes etnias africanas que colonizaram o Brasil por mais de 300 anos. Apesar do reconhecimento de genéricas "heranças africanas" na mestiçagem cultural brasileira, a imagem dos africanos de primeira geração se diluiu rapidamente na memória popular ao longo do século XX, depois que a lembrança de sua presença viva morreu com aqueles que tinham conhecido os últimos africanos sobreviventes, trazidos ainda crianças nos últimos anos do tráfico de escravos. Hoje, renovado interesse por parte dos descendentes de africanos nas Américas e inédita colaboração entre africanistas e especialistas nas populações negras nas Américas e em outros continentes apontam para uma "redescoberta" da África espalhada pelo mundo. O Brasil, tendo recebido aproximadamente um terço de todos os escravos trazidos para as Américas durante os três séculos de duração do tráfico atlântico, é terreno importante desta busca. ${ }^{1}$

Com efeito, nos últimos dez anos, a colaboração entre historiadores sediados em diferentes regiōes deu força às investigações detalhadas sobre as relações comerciais das regiōes africanas com outros continentes, sobre o volume, direção e funcionamento do tráfico de escravos através do Atlântico e na direção do Mediterrâneo, e especialmente sobre a experiência das pessoas envolvidas nestes intercâmbios comerciais e culturais, com foco especial, naturalmente, sobre as pessoas escravizadas levadas como mercadoria para outras partes do mundo. A experiência dos africanos na diáspora é o objeto central e unificador dos interesses dispersos e multidisciplinares engajados nesta ampla investigação. ${ }^{2}$ Envolvendo metodologias diversas, das pesquisas demográficas quantitativas à microhistórica reconstituição de trajetórias de vida, este campo de estudos já tem algumas questôes e achados comuns. Tem também muitas lacunas. Este trabalho pretende discutir o caminho percorrido e as perspectivas da história da diáspora afri- 
cana no Brasil, os autores e obras que lhe servem de referência, as fontes e suas limitações e a potencial contribuição desta área para a historiografia brasileira.

\section{Os africanos na historiografia brasileira}

Os estudos pioneiros sobre a experiência africana no Brasil pertencem ao campo da antropologia e têm no livro Os Africanos no Brasil, do médico Nina Rodrigues, um de seus marcos iniciais. ${ }^{3}$ Resultado de pesquisa conduzida por Nina Rodrigues entre africanos remanescentes na Bahia do fim do século XIX, mas só publicada, postumamente, em 1932, o livro tinha objetivos claros: identificar os traços físicos e culturais africanos que haviam se infiltrado na "raça" brasileira durante os séculos anteriores, resultante da maciça importação de africanos pelo tráfico atlântico e de intensa miscigenação. A reflexão do médico era inspirada pela ideologia racista que atribuía à miscigenação os males e entraves ao desenvolvimento do país, porque a "civilização" estava associada a uma população de cor branca e hábitos europeus. O estudo científico dos costumes indesejáveis permitiria avaliar quanto tempo sua influência marcaria negativamente a cultura brasileira. ${ }^{4} \mathrm{O}$ trabalhoso inventário de informações e informantes acerca dos africanos compilado por Nina Rodrigues provou ser muito mais valioso do que suas interpretações e prognósticos e serviu de inspiração para uma geração subseqüente de investigadores.

Nina Rodrigues traçou amplo quadro da presença africana no Brasil ao discutir suas regiōes de procedência conforme a distribuição do tráfico de escravos, ao inventariar as línguas e grupos étnicos africanos existentes no Brasil e ao reconhecer a complexidade de suas manifestações artísticas e religiosas. $\mathrm{O}$ médico também abordou a presença de muçulmanos entre os escravos baianos e seu engajamento na resistência à escravidão nas célebres revoltas que culminaram em 1835 com o levante dos malês em Salvador. Nina Rodrigues atribuía aos africanos da Costa Ocidental - iorubás, jejes, tapas, haussás - superioridade cultural em relação aos bantos, provenientes da África Centro-Ocidental, que eram maioria no centro-sul do Brasil.

As investigações de Nina Rodrigues abriram caminho para outros autores explorarem as manifestações culturais de origem africana no Bra- 
sil. Na segunda geração estes estudos tiveram motivação diferente, uma vez que as ciências sociais no Brasil rejeitaram a visão negativa corrente da miscigenação racial e passaram a vê-la, ao contrário, como ponto fundamental da identidade brasileira. A transformação operada no pensamento social brasileiro pelo relativismo cultural trazido da antropologia americana por Gilberto Freyre foi crucial para a valorização da "herança" africana na cultura brasileira. A nova perspectiva contribuiu para o nascimento de um ramo de "estudos afro-brasileiros", que foi bastante fértil nos anos 1940 e 1950. Os trabalhos, em geral de cunho etnográfico, têm explícita concentração em temas relativos às práticas religiosas afro-brasileiras, consideradas as remanescentes mais vivas da cultura africana. Aos poucos, o interesse pelos africanos de primeira geração se transferiu para os "negros" em geral e se diluiu em tais investigações de uma "cultura negra" genérica. ${ }^{5}$

Nas décadas de 1950 e 1960, pesquisa e intenso debate acerca das relações raciais no Brasil marcou o ramo dos estudos afro-brasileiros: tratava-se de contestar a idéia difundida a partir da obra de Gilberto Freyre, de que o Brasil constituía uma "democracia racial", porque a miscigenação teria prevenido o racismo à americana. Pesquisa sociológica rigorosa demonstrou os mecanismos sutis da discriminação racial no país e alimentou pesquisas históricas que procuravam dissipar as imagens de uma escravidão benevolente ao mostrar a violência envolvida na relação senhor-escravo e na manutenção do sistema escravista. ${ }^{6}$ Foi através desta preocupação com as relaçôes raciais e com o objetivo de explicar o funcionamento do sistema escravista que a experiência das populações de origem africana passou a ser explorada por historiadores no Brasil. ${ }^{7}$

Depois de uma geração de historiadores engajada em desmontar o mito da escravidão benevolente, através de estudos sobre a violência no sistema e sobre a resistência escrava, sobretudo violenta, assumiu o debate uma nova geração preocupada com o cotidiano dos escravos e com a variedade de relações dentro do sistema escravista. A nova perspectiva da escravidão se abre com pesquisa empírica intensiva em materiais manuscritos antes inexplorados, como inventários post-mortem, processos-crime, ações de liberdade, correspondência policial, além de uma leitura "a contrapelo" de relatos de viajantes e de documentos oficiais. ${ }^{8}$ A pesquisa revela com riqueza de detalhes o funcionamento das relações no sistema escravista e a vida dos 
escravos propriamente. Enquanto antes os escravos eram vistos como uma massa uniforme, agora percebe-se uma hierarquia entre escravos, e o entrecruzar de identidades, baseadas em gênero, idade, ocupação (escravos rurais, urbanos, domésticos, artesãos, ganhadores etc.) e origem (africanos de diversas etnias ou nascidos no Brasil). Assim, na busca da diversidade das experiências históricas da população escravizada, os historiadores chegaram aos africanos e à sua experiência distinta, para a qual Nina Rodrigues havia apontado quase um século atrás.

\section{Caminhos delimitados de uma busca}

Apesar da existência de alguns "marcos" na historiografia sobre africanos no Brasil, a maior parte das referências à experiência africana está dispersa na literatura que lida com os vários aspectos da escravidão: trabalho, família, resistência, religião etc. Graças ao intercâmbio entre historiadores brasileiros e especialistas na história dos africanos em outras regiōes da diáspora, a área de estudos propriamente africanistas no Brasil começa a se constituir em área destacada da grande área de estudos da escravidão. Isso porque a própria comparação das experiências dos africanos nas diversas regiōes fora da África suscita debates próprios, relacionados com a experiência escrava, mas não centrados apenas nela. ${ }^{9}$

O objeto de estudos tem imposto um recorte temático e uma metodologia próprios. A busca pela experiência propriamente africana é a tentativa de distingui-la da experiência dos seus descendentes nascidos no local onde se fixaram, dos colonizadores europeus e dos nativos, e mais tarde dos imigrantes. Isso significa centrar-se somente nos africanos de primeira geração: seguir seus passos relutantes, seu desenraizamento forçado, sua ressocialização em terras estrangeiras. Implica estudar pelo período de uma vida apenas as sucessivas levas de homens, mulheres e crianças trazidos pelo tráfico transatlântico desde o século XVI até meados do século XIX. Além disso, implica tentar descobrir as marcas e memórias deixadas por esta primeira geração nas gerações subseqüentes. A busca segue em dois níveis: um coletivo, agregado, o das relaçóes comerciais, intercâmbios diplomáticos e culturais e das rotas do tráfico de escravos; outro individual, microscópi$\mathrm{co}$, que procura por pessoas, ou pequenos grupos. Isso porque cumpre sem- 
pre identificar os africanos, seja em trajetórias individuais ou coletivas. Cumpre ligá-los pelo menos ao continente, mas idealmente identificar sua região de origem, senão cidade, vilarejo e etnia. Ainda que esta proposta suscite alguns problemas teóricos e metodológicos, o conjunto das pesquisas recentes tem mostrado sua viabilidade.

Um roteiro da investigação da história da experiência africana no Brasil começa necessariamente pelas rotas do tráfico de escravos. De onde vinham os escravos africanos que para cá foram trazidos entre os séculos XVI e XIX? Quais as condições de sua escravização? De que portos embarcaram? Qual sua experiência na travessia atlântica? Onde desembarcaram e quais as rotas terrestres que fizeram até chegar ao local onde se encontravam trabalhando? Essas questões foram abordadas recentemente por Mariza Soares de forma original, ao buscar identificar os africanos de um grupo étnico conhecido no Rio de Janeiro setecentista como "mina-mahi”. Ela procurou retraçar os passos dos africanos daquele grupo no Brasil, identificando as rotas atlânticas e terrestres que os traziam para o sudeste através da Bahia. ${ }^{10}$ Semelhante esforço foi empreendido por Mary Karasch para descobrir os caminhos que levavam africanos bantos a Goiás Velho. ${ }^{11}$ Tais esforços são correspondidos pelos de outros pesquisadores em outras partes do Atlântico, reunidos em torno do projeto da UNESCO intitulado "A Rota dos Escravos". O conjunto das pesquisas tem permitido traçar no tempo trajetórias de grupos étnicos através do Atlântico e observar sua dispersão geográfica nas Américas. Avanços nos estudos das direçôes e volume do tráfico têm contribuído para isso. Resultado palpável encontra-se no banco de dados de viagens transatlânticas compilado por David Eltis, que cobre toda a duração do tráfico e todas as regiōes de embarque e desembarque de africanos, permitindo traçar a freqüência e o volume das ligações, porém apenas inferir as origens étnicas dos escravos a partir dos portos de embarque. ${ }^{12}$ Tais achados têm o imenso potencial de guiar os historiadores no estudo das manifestações culturais de regiões que, como a Bahia e o Golfo do Benin, ou a Louisiana e a Senegâmbia, têm profunda afinidade, porque foram ligadas por intenso tráfico de escravos. Também pautam o caminho dos estudos qualitativos que se concentram na diáspora de grupos culturais específicos, como os centro-africanos ou os iorubá. ${ }^{13}$ 
As rotas do tráfico de escravos para o Brasil tiveram abordagem pioneira no trabalho de Pierre Verger, em que demonstrou a estreita ligação comercial entre os portos de Salvador e os do Golfo do Benin, na Costa Ocidental africana entre os séculos XVII e XIX, relação que se traduziu em intenso tráfico de escravos e mercadorias, em intercâmbio cultural, relações familiares dos dois lados do Atlântico e até a adoção de hábitos e práticas "brasileiros" naquela região da África, graças ao que Verger batizou de "refluxo", a volta de africanos alforriados com suas famílias e dependentes. ${ }^{14}$ Tal relação comercial privilegiada foi favorecida pela proximidade geográfica das duas regióes e alimentada pelo estabelecimento de sociedades entre comerciantes e traficantes dos dois lados do Atlântico. A peculiaridade deste ramo do tráfico de escravos determinou a superioridade numérica dos africanos da Costa Ocidental - iorubás, tapas, haussás, jejes - na composição étnica da população africana da Bahia, principalmente no século XIX. ${ }^{15}$

Semelhante relação entre o Rio de Janeiro e Angola tem recebido atenção dos historiadores recentemente. Na composição étnica da população africana do Rio de Janeiro sempre predominaram os africanos da Costa Centro-Oriental, provindos dos grandes portos de Luanda, Cabinda e Benguela. ${ }^{16}$ As condições de sua escravização na grande "hinterland" angolana e congolesa e as altas taxas de mortalidade do tráfico angolano foram descritas e discutidas em detalhe por Joseph Miller, em estudo que traça magistralmente as relaçôes comerciais nos níveis local, regional e internacional que compunham o tráfico de escravos de Angola. ${ }^{17}$ Outros estudos seguem a rota dos escravos que saíam de Angola e chegavam no Rio de Janeiro. ${ }^{18}$ Menos numerosos são os trabalhos que propõem detalhar os caminhos que levavam ao interior, no centro-sul do país. A exploração das rotas terrestres, marítimas de cabotagem ou ainda fluviais, para a investigação das rotas internas do tráfico de escravos por todo o país há de ser o tema mais promissor, dentre os ainda pouco explorados nesta área. $\mathrm{O}$ hipotético mapa das "rotas dos escravos" no Brasil seria completo com trabalhos acerca do tráfico atlântico conduzido a partir de pontos que não fossem o Rio de Janeiro ou a Bahia, com suas respectivas rotas do tráfico interno. Por que caminhos passavam os escravos africanos encontrados nas charqueadas rio-grandenses, por exemplo? 
Tamanha reconstituição das rotas seria facilitada pelo levantamento nominal dos africanos em listas de batismo, casamento e óbito em todas as remotas regiōes do país onde eles chegaram. ${ }^{19} \mathrm{Tal}$ levantamento viabilizaria, além do estudo da proporção da população africana na população total nas regiōes do país e ao longo dos três séculos, o de sua composição étnica. Quem eram os africanos que foram trazidos para o Brasil? Os estudos do tráfico de escravos já demonstraram que vinham de três grandes regiōes: da Costa Ocidental da África (Costa da Mina principalmente), da África Centro-Ocidental (Angola-Congo) e da Costa Oriental (Moçambique). O trabalho de identificação individual dará detalhes de suas origens, conforme os etnônimos registrados. Pesquisa semelhante, com registros de "nação" e com nomes próprios dos africanos capturados no tráfico ilegal em Cuba e em Serra Leoa, demonstrou a possibilidade de associação destas identificaçôes com as localidades específicas de origem dos africanos no interior da Costa Ocidental. ${ }^{20} \mathrm{Na}$ identificação étnica reside a chave para responder muitas questôes da experiência africana na diáspora; os problemas teórico-metodológicos que ela suscita são centrais para esta área de estudos.

\section{Etnia, etnônimos, etnicidade}

A reconstituição de trajetórias coletivas de grupos de africanos na diáspora baseia-se na associação entre elementos do grupo transplantado e elementos semelhantes remanescentes em uma região ou localidade africana. Sejam eles língua, práticas religiosas, ou simplesmente etnônimos (nomes pelos quais uma etnia se identifica), precisam ser traçados de lado a outro do Atlântico. As designações étnicas e de origem, comumente chamadas de "naçôes" nos registros históricos, são os elementos que mais nos aproximam de uma associação dos indivíduos com seus específicos locais de origem. Ora, um estudo detalhado destas designações demonstra que muitas vezes elas nos dizem mais sobre o tráfico, ou os colonizadores, do que sobre os africanos eles mesmos. Como seria possível traçar a "ponte" com a África, não só reconhecendo que os africanos traziam distinta cultura, mas tentando decifrar suas variaçōes?

Segundo Mariza Soares, o universo semântico que recobre o conjunto das procedências ou nações é variado: "Não existe qualquer homoge- 
neidade nos nomes das procedências: vão desde os nomes de ilhas, portos de embarque, vilas e reinos a pequenos grupos étnicos." ${ }^{21}$ Assim, no conjunto dos registros de "nações" que um historiador vai manipular, existirão registros genéricos como "Angola”, que designa africanos que passaram pelo porto de Luanda, "Cassange", para os que foram comerciados no mercado deste nome a oeste do Rio Coango, ou mais específicos como "Uamba", grupo da região a leste do porto de Benguela. ${ }^{22}$ Mas, em geral, os registros de nação tendem a reagrupar pequenos grupos étnicos sob identidades maiores, como "Mina" ou "Congo", ou a identificar os escravos africanos genericamente como "de nação". Isto é, em geral, os registros de nação denotam identidades construídas do lado de cá do Atlântico.

Os registros de nação encontrados na documentação - nos assentos de batismo, casamento e óbito, nas matrículas e nos relatos dos memorialistas - representariam tanto as categorias criadas pelos senhores e comerciantes do tráfico, preocupados com a classificação e identificação dos escravos sob sua autoridade, quanto as identidades adotadas pelos próprios africanos ao se reagruparem e ressocializarem sob a escravidão. Os historiadores trabalhando com os registros de nação africanos no Brasil e em outras partes da diáspora africana têm apontado para o funcionamento desse processo de re-significação das identidades étnicas sob a escravidão. Os estudos se baseiam no uso de um conceito antropológico de etnia renovado: hoje se trabalha com a idéia de que as identidades étnicas são construídas com base em determinados elementos da cultura de um grupo, conforme se necessita compor o grupo em relação aos outros em torno. É portanto uma identidade em constante transformação. ${ }^{23}$ Sob esta perspectiva, o momento da passagem transatlântica e os primeiros anos sob a escravidão nas Américas teriam servido como ruptura e redefinição das identidades étnicas.

Como lidar com os registros de nação se eles não traduzem as etnias africanas que nos permitiriam associá-los a grupos e regiōes específicos? Se, por um lado, não se pode associar diretamente as práticas culturais de um e outro lado do Atlântico, como faziam folcloristas e antropólogos no início das investigações sobre as culturas afro-americanas, também não se pode afirmar que o trauma da travessia atlântica e da escravização tenham apagado os traços culturais de origem nos africanos nas Américas, fazendo-os construir uma cultura mestiça baseada na experiência comum da escravi- 
dão somente. $\mathrm{O}$ conjunto dos estudos que vêm sendo realizados com base nas identidades étnicas dos africanos nas Américas apontam para saídas do dilema através de soluçôes originais.

Robert Slenes sugeriu que os grupos étnicos de língua banto, provenientes da África Centro-Ocidental, majoritários no Sudeste oitocentista, teriam chegado a níveis de identificação e associação tão próximos a ponto de formar uma "proto-nação banto". Isso porque os africanos de diversas etnias estariam em colaboração em torno de uma grande revolta escrava nas fazendas do Vale do Paraíba carioca e paulista, sufocada em 1848. As evidências documentais a corroborarem tal interpretação são infelizmente escassas. ${ }^{24}$ Em trabalho posterior, Slenes avança na identificação da composição da "proto-nação banto" ao cuidadosamente associar elementos de sua cultura material (formas de construção de casas) e práticas simbólicas (o uso do fogo) a elementos semelhantes nas regiōes de origem dos africanos na África Centro-Ocidental. ${ }^{25} \mathrm{~A}$ cuidadosa coleta e interpretação crítica de práticas e elementos materiais comuns dos dois lados do Attântico é uma das soluçóes para o trabalho de retraçar trajetórias dos africanos. Historiadores de outras regiōes das Américas têm se valido deste método. Assim, enquanto Peter Wood havia sugerido a associação entre os escravos africanos e o começo do cultivo do arroz na colônia norte-americana da Carolina do Sul, Judith Carney deu um passo adiante e relacionou a prática de cultivo de arroz dos africanos da Costa do Ouro, a oeste da Costa da Mina, à implantação, técnicas e transformações do cultivo do arroz, produto que veio a ser para a Carolina do Sul o que o café foi para São Paulo. ${ }^{26}$ Igualmente, Gwendolyn Midlo-Hall cuidadosamente pinçou as evidências da presença dos africanos Bambara na Louisiana sob o domínio francês para atribuir àquele grupo especificamente papel importante na formação da cultura afro-crioula naquela região no século XVIII. ${ }^{27}$ Também Monica Schuler reconstituiu, através de documentação histórica e de testemunhos orais dos descendentes, as práticas culturais dos africanos centro-ocidentais trazidos sob regime de contrato para a Jamaica em meados do século XIX. ${ }^{28}$

A outra solução para o dilema da investigação em torno das etnias africanas é empreender o trabalho de decifrar a construção histórica das identidades étnicas e suas transformações entre o período de duração do 
tráfico e o da sobrevivência dos africanos nas Américas. Sem assumir a associação direta entre os etnônimos usados dos dois lados do Atlântico, ou mesmo a manutenção de seus significados em períodos e regiões distintas, o trabalho do historiador passa a ser o de documentar os processos de delimitação das fronteiras de identificação étnica através dos quais os grupos constróem suas diferenças. ${ }^{29}$ Assim pode-se com cuidado identificar as origens de grupos cujos nomes do lado de cá do Atlântico se alteraram, porque se fundiram com outros. Exemplo deste exercício se encontra na tese de Maria Inês de Oliveira sobre a construção da identidade nagô na Bahia oitocentista: ela mostrou que não apenas os majoritários iorubás, mas também indivíduos de grupos menores, como jejes, haussás e tapas passaram a reconhecer-se sob uma identidade "guarda-chuva" nagô e que suas identidades de origem apareciam só quando a distinção dentro do grupo se fazia necessária. ${ }^{30}$ Mariza Soares buscou elucidar as variaçōes da identidade "Mina" no Sudeste, que era diferente da baiana e se transformou entre os séculos XVIII e XIX. "Mina" no Sudeste identificava todos os africanos da Costa Ocidental que na Bahia tinham identidades separadas porque lá eram proporcionalmente muito mais numerosos. ${ }^{31}$ Mieko Nishida, por outro lado, estudou para Salvador no século XIX a formação de uma identidade africana, por oposição à identidade crioula, que reunia escravos e libertos e superava as identidades ligadas às nações. Nishida viu nas manifestações de resistência dos africanos e nas reações de perseguição e discriminação que sofreram fatores de aglutinação para a consolidação desta identidade africana, "estrangeira". ${ }^{32}$

\section{Trilhas identificadas}

O roteiro da investigação histórica da experiência africana no Brasil, tendo passado pelas rotas do tráfico atlântico e interno e pelo difícil desafio da identificação pelas etnias e nações, segue por caminhos que estão apenas indicados por alguns trabalhos importantes. Tais trabalhos, como lanternas, ajudam a identificar fontes disponíveis e perspectivas possíveis neste fértil campo de estudos. Destacam-se porque, além de dialogar com a história social e cultural da escravidão no Brasil, buscam identificar os africanos e dar detalhes de suas experiências distintas. São ainda relativa- 
mente pouco numerosos e concentram-se no século XIX, mas dão uma amostra do que as fontes brasileiras, notoriamente mais volumosas do que em outras partes das Américas, guardam nos arquivos.

A história do trabalho no Brasil será certamente beneficiada quando os historiadores passarem a observar os escravos mais de perto e perceberem as experiências africanas em mais detalhe. Em que elas teriam sido diferentes das dos escravos nascidos no Brasil? Seguindo o exemplo dos estudos sobre o arroz na Carolina do Sul, os historiadores poderiam explorar o campo do emprego das aptidóes específicas de determinados grupos de africanos em determinadas ocupações: mineração, pesca, cultivo agrícola, derrubada da mata etc. Eduardo Spiller Pena, seguindo o método indiciário, vem trabalhando com os elementos culturais centro-africanos e particularmente as práticas de fundição de metais entre os quilombolas de Minas Gerais. ${ }^{33}$ Dentro desta exploração caberia certamente se perguntar se a tradicional divisão sexual de tarefas se repetiu do lado de cá do Atlântico. Nos debates sobre a escravidão, a "negociação" entre escravos e senhores tem sido enfatizada; cumpre descobrir quanto desta negociação se relacionava às tentativas dos africanos de conseguirem adaptar suas tarefas, ritmos de trabalho e lazer aos seus próprios hábitos ancestrais. $\mathrm{O}$ mais vívido exemplo de negociação, o "tratado" proposto por escravos aquilombados da região do recôncavo baiano a seu senhor em 1789 sugere pistas: os escravos que propuseram as condiçôes para a volta ao trabalho não aceitavam certas tarefas, como mariscar, para as quais o senhor deveria "mandar seus pretos Minas". ${ }^{34}$ Além de uma questão de rivalidade inter-étnica ou entre crioulos e africanos, a recusa em executar certas funções poderia se relacionar com aptidões ou limitações trazidas de sua região de origem. Há uma interessante referência ao cultivo de arroz, pelos próprios escravos para seu sustento neste tratado. Sabendo que o arroz era a base alimentar para muitos grupos na África, e tendo em vista a história da Carolina do Sul, abre-se outra trilha de investigação: a influência africana na composição alimentar e no cultivo das roças dos próprios escravos.

Também na escravidão urbana encontram-se roteiros para a investigação da experiência africana. João Reis vem estudando o trabalho "ao ganho", isto é, de pessoas que ficavam nas ruas de Salvador a oferecerem seus préstimos para os mais variados serviços, pagos por tarefa. Os "ganha- 
dores" de Salvador reuniam-se em torno de "cantos", ou grupos de trabalho organizados por etnias. Os cantos, nas palavras de João Reis, "haviam se constituído historicamente como verdadeiras instituiçôes africanas em Salvador" porque neles sempre predominaram africanos, escravos ou libertos, até os últimos anos da escravidão. Ao mostrar em detalhe a composição dos cantos em 1887, quando os brasileiros já compunham metade dos trabalhadores registrados, Reis dá um exemplo de análise que incorpora classe, raça e etnia efetivamente e ainda aponta para a convergência dos trabalhadores em torno de uma identidade de classe negra. ${ }^{35}$ Mary Karasch descreveu as ocupaçôes de escravos em geral, com algum detalhe sobre africanos, no Rio de Janeiro da primeira metade do século. ${ }^{36}$ Outros trabalhos têm buscado discernir a presença africana entre os trabalhadores urbanos, principalmente nos ramos de atividades em que eram mais numerosos, como as atividades portuárias. ${ }^{37}$ Esse quadro suscita mais perguntas do que propriamente respostas. O que teria favorecido a concentração dos africanos em determinadas ocupações urbanas? Que papel tiveram nas suas experiências de trabalho as heranças de seus pais e antepassados? Qual o envolvimento dos africanos nas sociedades de ajuda, juntas de alforria, irmandades e outras formas de organização dos negros urbanos?

Os estudos sobre as práticas culturais e a resistência dos escravos têm revelado alguns padróes propriamente africanos. Estudo pioneiro no trabalho de revelar a África no Brasil, o livro de João Reis sobre a revolta dos malês em Salvador em 1835 mostrou que os escravos e libertos muçulmanos que organizaram a revolta haviam sido escravizados em guerras de conquistas religiosas que alimentaram seu espírito guerreiro. ${ }^{38}$ Reis explica a interrelação entre etnia, religião e classe na composição do grupo revoltoso, de forma a decifrar os "interesses" de cada um dos grupos - nagôs e etnias aliadas, muçulmanos ou não, escravos e libertos - na busca da sua própria liberdade. Nisso fez trabalho inédito na historiografia da resistência escrava. ${ }^{39}$ Seguindo os passos de João Reis, outros historiadores vêm buscando as referências às identidades étnicas e reconstituindo cenas do cotidiano africano em várias partes do Brasil: a descrição dos zungus, casas de angu e dormitórios por onde circulavam africanos minas e de outras etnias no Rio de Janeiro oitocentista, é um dos melhores exemplos desta safra de trabalhos. ${ }^{40}$ 
A busca das práticas religiosas africanas é, mais do que uma trilha, um caminho já consolidado. Vários estudos apontam para a documentação da experiência propriamente africana. Entre eles se destacam o levantamento conduzido por Laura de Mello e Souza dos processos inquisitoriais contra "feitiçaria" praticada por africanos e seus descendentes na colônia, os estudos de João Reis sobre a repressão aos locais de culto na Bahia, sua investigação de como as práticas funerárias africanas tiveram peso sobre as baianas, ou ainda a associação da resistência imposta pela população negra carioca à vacina da varíola às suas crenças e práticas rituais associadas ao orixá Omolu, revelada por Sidney Chalhoub. ${ }^{41}$ As referências a africanos se multiplicam na documentação; os novos estudos revelam que os historiadores estão agora dispostos a percebê-las e a interpretá-las.

$\mathrm{O}$ olhar africanista percebe novos indícios em velhos documentos. $\mathrm{O}$ melhor exemplo disso está na nova interpretação dada às cartas de alforria. James Sweet e Manolo Florentino, ambos estudando o Rio de Janeiro em períodos distintos, demonstraram que a alforria não alcançava igualmente crioulos e africanos, e, além disso, também não alcançava igualmente os africanos das diferentes nações. Enquanto os escravos crioulos tendiam a conseguir alforrias gratuitas com mais freqüência, os africanos predominavam entre os que pagavam pela liberdade. Além disto, entre os africanos aqueles da Costa Oriental, em maior proporção do que seu peso na população, conseguiam alforrias mediante prestação de serviço, arranjo com o qual os da Costa Centro-Ocidental raramente concordavam. Estes últimos, reforçando sua imagem de escravos ao ganho que acumulavam pecúlio, predominavam entre os que pagavam por suas alforrias. Assim, dissipa-se a noção simplista de que as alforrias eram puramente concessões senhoriais, mostrando o quanto os escravos trabalhavam para isso, e de forma diferente conforme sua origem. Por outro lado, os estudos destacam a experiência africana na escravidão, mostrando que era mais difícil para um escravo africano do que para um crioulo conseguir a liberdade. ${ }^{42}$

$\mathrm{Na}$ fronteira dos estudos sobre os africanos na diáspora estão as reconstituições de trajetórias de vida. Ao contrário das biografias de pessoas que deixaram registros escritos e cuja memória passou para a história, estas reconstituições buscam as trajetórias de africanos escravizados que ficaram muitas vezes anônimos. Suas vidas ilustram as vidas de tantos ou- 
tros que são em geral vistos só coletivamente, seja como números do tráfico, ou como massa de escravizados. Philip Curtin e Pierre Verger já haviam apontado para biografias de africanos e libertos cujas trajetórias foram excepcionais, como a do reverendo Samuel Crowther, africano recapturado do tráfico em Serra Leoa no século XIX que tornou-se missionário e bispo anglicano e contribuiu para o estudo das línguas iorubá, ibo e hausa. ${ }^{43}$ Paul Lovejoy e Robin Law trabalharam recentemente em retraçar e documentar a trajetória de Mahoma Baquaqua, um africano da Costa Ocidental, muçulmano, que foi escravo no Brasil e daqui fugiu para os Estados Unidos, onde publicou sua biografia. ${ }^{44}$ Outros trabalhos vêm revelando personagens até então desconhecidos, agora com nomes e às vezes faces, que tiveram trajetórias excepcionais, como a do africano Tito Camargo, que aglutinou a sociedade campineira oitocentista em torno da construção da igreja de São Benedito, ou do barbeiro mina Inácio Monte, líder da Congregação dos Pretos Minas do Reino de Mahi no Rio de Janeiro setecentista. ${ }^{45}$ Trabalho necessariamente difícil e incompleto, mas de grande potencial, a reconstituição de trajetórias de vida de africanos antes anônimos permite vê-los na variedade da sua experiência e mudar o foco da historiografia que até então os vitimizou. $\mathrm{O}$ resgate da história dos africanos permite, antes de mais nada, mostrá-los como agentes da própria história.

\section{Conclusão: perspectivas abertas}

Ao contrário dos africanos na Colômbia ou em Serra Leoa, os que foram trazidos para o Brasil nunca despertaram interesse em seus senhores por sua cultura e origens. O trabalho de registro de histórias da África através de entrevistas aos africanos escravizados empreendido pelo padre Pedro Claver, em Cartagena das Índias, no século XVII, ou aquele empreendido pelo missionário Koelle entre africanos livres de diversas etnias em Serra Leoa, no século XIX, ao registrar suas línguas, não têm paralelo no Brasil, país das Américas que mais recebeu africanos. ${ }^{46}$ Isso porque historicamente os senhores só se preocupavam com as diferenças entre seus escravos na hora de dividir para conquistá-los; só lhes interessava a vida dos escravos depois do seu desembarque. De certa forma, a historiografia brasileira vinha repetindo esta prática ao ignorar a África e as diferenças entre os africanos que colonizaram o país. 
Este artigo apontou para os contornos de uma área de estudos em formação, que tem por objeto a experiência africana no Brasil. Enraizada na historiografia da escravidão, ela cresce apoiada em estudos sobre a experiência africana em outras regióes da diáspora. Trata-se de reconstituir trajetórias individuais e de grupos através do Atlântico e de historicizar sua experiência. Trata-se de buscar entender o processo através do qual indivíduos de diversas origens, línguas e religiōes se integraram, entre eles e com os que já habitavam a colônia. Este processo de transformaçóes culturais não cabe nos conceitos de assimilação, aculturação ou mestiçagem. Michael Gomez chama-o de "troca das marcas tribais" por uma identidade negra referindo-se à experiência norte-americana, mas semelhante homogeneidade talvez não tenha existido no Brasil. ${ }^{47} 48$ Trata-se, antes de tudo, de resgatar a multiplicidade das culturas que compuseram a população brasileira e de rejeitar a idéia da convergência para a formação de uma só cultura, de raiz (ou alma) branca. Trata-se, num sentido historiográfico, de abrir a perspectiva da história brasileira na direção do Atlântico e colocá-la em termos comparativos com as histórias das outras regiōes escravistas do mundo.

\section{Notas}

${ }^{1}$ As estimativas do volume total do tráfico atlântico geraram intensa controvérsia, mas o cálculo de Philip Curtin costuma ser reconhecido como correto, mesmo depois da contagem individual das viagens transatlânticas experimentada recentemente. Ver Curtin, Philip D. The Atlantic Slave Trade: a census. Madison: University of Wisconsin Press, 1969; Eltis, David et al. The Transatlantic Slave Trade, CD-ROM. Cambridge University Press, 1999; Florentino, Manolo. Em Costas Negras: uma história do tráfico de escravos entre a Africa eo Rio de Janeiro. São Paulo: Companhia das Letras, 1997.

${ }^{2}$ A multiplicação de congressos acadêmicos, de programas de pós-graduação e de centros de pesquisa dedicados à diáspora africana é demonstração desse movimento.

${ }^{3}$ Rodrigues, Nina. Os africanos no Brasil. São Paulo: Cia. Editora Nacional, 1932.

${ }^{4}$ As origens e argumentos da ideologia racista no Brasil são discutidos em detalhe por Lília Schwartz; Schwarcz, Lilia Moritz. O Espetáculo das Raças: Cientistas, Instituiçōes e Questão Racial no Brasil, 1870-1930. São Paulo: Companhia das Letras, 1993. Ver também sua didática apresentação da "questão racial" no Brasil: Schwarcz, Lilia Moritz. Questão Racial no Brasil In: Negras Imagens: ensaios sobre cultura e escravidão no Brasil, eds. Lilia Moritz Schwarcz e Letícia Vidor de Sousa Reis. São Paulo: EDUSP/Estação Ciência, 1996, 153-177. 
${ }^{5}$ Freyre, Gilberto. Casa Grande e Senzala. 20 ed. Rio de Janeiro/Brasília: Instituto Nacional do Livro, 1980 [1933]; Ramos, Artur. O negro no Brasil. Rio de Janeiro: Civilização Brasileira, 1940; Carneiro, Edison. Religiōes negras. Rio de Janeiro: Civilização Brasileira, 1936; Querino, Manuel. Costumes Africanos no Brasil, 2a ed. Recife: Fundação Joaquim Nabuco/Ed. Massangana, 1988; Bastide, Roger. As religióes africanas no Brasil. São Paulo: Pioneira, 1985.

${ }^{6}$ Fernandes, Florestan. O negro no mundo dos brancos. São Paulo: Difel, 1972; Costa Pinto, Luiz Aguiar. O negro no Rio de Janeiro: relaçôes de raça numa sociedade em mudança, 2a ed. Rio de Janeiro: Editora UFRJ, 1998 [1953]; Cardoso, Fernando Henrique e Ianni, Octávio. Cor e mobilidade social em Florianópolis. São Paulo: Nacional, 1960; Cardoso, Fernando Henrique. Capitalismo e Escravidão no Brasil Meridional. São Paulo: Difel, 1962.

${ }^{7}$ Costa, Emília Viotti da. Da Senzala à Colônia,. São Paulo: Difel, 1966; Queiroz, Suely Robles Reis de. Escravidão Negra em São Paulo: um estudo das tensóes provocadas pelo escravismo no século XIX. Rio de Janeiro: Livraria José Olympio Editora, 1977.

${ }^{8}$ Mello e Souza, Laura. O Escravismo Brasileiro nas Redes do Poder: Comentário de Quatro Trabalhos Recentes sobre Escravidão Colonial. Estudos Históricos 2.3. 1989. p. 133-152; Lara, Sílvia Hunold. Escravidão no Brasil: Balanço Historiográfico, LPH: Revista de História 3.1. 1992. p. 215-239. Dos trabalhos da "nova geração" se destacam: Lara, Sílvia Hunold. Campos da Violência: escravos e senhores na capitania do Rio de Janeiro, 1750-1808. Rio de Janeiro: Paz e Terra, 1988; Chalhoub, Sidney. Visões da Liberdade: uma história das últimas décadas da escravidão na Corte. São Paulo: Companhia das Letras, 1990; Fragoso, João Luis Ribeiro e Florentino, Manolo. O Arcaísmo como Projeto: Mercado Atlântico, Sociedade Agrária e Elite Mercantil no Rio de Janeiro, c.1790-c.1840. 4a . ed. Rio de Janeiro: Civilização Brasileira, 2001.

${ }_{9}^{9}$ Para uma excelente proposta de releitura da história colonial brasileira à luz dos novos estudos africanistas, ver Russell-Wood, A.J.R. Através de um prisma africano: uma nova abordagem no estudo da diáspora africana no Brasil colonial. Tempo 12 (dez. 2001). pp. 11-50.

${ }^{10}$ Soares, Mariza de Carvalho. Os Mina em Minas: Tráfico Atlântico, Redes de Comércio e Etnicidade. Anais do XX Simpósio Nacional da ANPUH - História: Fronteiras, eds. Nodari, Eunice, Pedro, Joana Maria e Iokoi, Zilda M. G. vol. 2. São Paulo: Humanitas/Anpuh, 1999, p. 689-685; Soares, Mariza de Carvalho. Mina, Angola e Guiné: Nomes d'África no Rio de Janeiro Setecentista. Tempo 3 (1998). pp. 73-93.

${ }^{11}$ Karasch, Mary. Central Africans in Central Brazil, 1780-1835 In: Central Africans and Cultural Transformations in the African Diaspora, ed. Heywood, Linda. Cambridge/Nova York: Cambridge University Press, 2002. pp. 117-151.

${ }^{12}$ Eltis, David et al., op.cit.

${ }^{13}$ Heywood, Linda (ed). Central Africans and Cultural Transformations in the African Diaspora. Cambridge: Cambridge University Press, 2002; Falola, Toyin e Childs, Matt (eds.). The Yoruba Diaspora in the Atlantic World. Bloomington: Indiana University Press, 2005.

${ }^{14}$ Verger, Pierre. Flux et reflux de la traite des nègres entre le golfe de Bénin et Babia de Todos os Santos du XVIIe au XIXe siècle. The Hague, Paris: Mouton, 1968; Carneiro da Cunha, 
Manuela. Negros, Estrangeiros: os escravos libertos e sua volta à África. São Paulo: Brasiliense, 1985; Guran, Milton. Agudás: os "brasileiros” do Benim. Rio de Janeiro: Nova Fronteira, 1999; Costa e Silva, Alberto da. Um Rio chamado Atlântico: a África no Brasil e o Brasil na África. Rio de Janeiro: Editora da UFRJ/Nova Fronteira, 2003.

${ }^{15}$ Estudos recentes têm avançado em direções instigantes, no tocante ao comércio entre o Brasil e a África. Ver, notadamente a biografia de Francisco Félix de Souza, traficante brasileiro radicado na costa ocidental da África, o comércio de aguardente e a questão do comércio dos objetos de culto, que continuou a ligar a África ao Brasil após a abolição do tráfico de escravos. Costa e Silva, Alberto. Francisco Félix de Souza: mercador de escravos. Rio de Janeiro: Nova Fronteira, 2004; Curto, José. Enslaving Spirits: The PortugueseBrazilian Alcohol Trade at Luanda and its Hinterland, c. 1550-1830. Leiden: Brill Academic Publishers, 2004; Santos, Flávio Gonçalves dos. A economia do Candomblé na Bahia: relaçôes comerciais em torno de objetos do culto afro-brasileiro de 1850 a 1837 . Comunicação apresentada no VI Congresso da Associação Latino-Americana de Estudos AfroAsiáticos no Brasil. Brasília, 2004.

${ }^{16}$ Florentino, op. cit.; Karasch, Mary. A vida dos escravos no Rio de Janeiro, 1808-1850. São Paulo: Companhia das Letras, 2000.

${ }^{17}$ Miller, Joseph C. Way of Death: Merchant Capitalism and the Angolan Slave Trade, 17301830. Madison: 1989.

${ }^{18}$ Rodrigues, Jaime. De costa a costa: cotidiano do tráfico negreiro, 1780-1860. Rio de Janeiro-Angola. Tese de Doutorado em História, UNICAMP, 2000; Ferreira, Roquinaldo Amaral. Brasil e Angola no tráfico ilegal de escravos. In: Angola e Brasil nas rotas do Atlântico Sul, eds. Pantoja, Selma e Saraiva, José Flávio Sombra. Rio de Janeiro: Bertrand Brasil, 1999. pp. 143-194 e Ferreira, Roquinaldo Amaral. Transforming Atlantic Slaving: Trade, Warfare and Territorial Control in Angola, 1650-1800. Tese de Doutorado em História, UCLA, 2003.

${ }^{19}$ Mariza Soares está envolvida em projeto para esse fim, relativo ao Rio de Janeiro: Ecclesiastical sources and historical research on the African Diaspora, coordenado por Jane Landers (Vanderbilt University) e financiado pelo National Endowment for the Humanities (EUA), desenvolvido em colaboração com Paul Lovejoy (Harriet Tubman Centre, York University). Coordeno projeto semelhante de levantamento de fontes eclesiásticas em Santa Catarina: Africanos no sul do Brasil: rotas do tráfico e identidade étnica, com financiamento da FUNCITEC/SC. O levantamento exaustivo de fontes contendo registros nominais de escravos e descendentes na Louisiana foi publicado por Gwendolyn Midlo Hall em Databases for the study of Afro-Louisiana History and Genealogy, 1699-1860. Computerized information from original manuscript sources. [CD-ROM] Baton Rouge: Louisiana State University Press, 2000. $O$ trabalho anterior de Mariza Soares para o Rio de Janeiro setecentista é um exemplo do potencial deste trabalho; Soares, Mariza de Carvalho. Devotos da cor: identidade étnica, religiosidade e escravidão no Rio de Janeiro, século XVIII. Rio de Janeiro: Civilização Brasileira, 2000.

${ }^{20}$ Nwokeji, Ugo e Eltis, David. The roots of the African diaspora: methodological considerations in the analysis of names in the Liberated African registers of Sierra Leone 
and Havana. History in Africa 29 (2002). p. 365-379. Ver também Durand, Guillaume. The survival of names of African origin in Martinique after emancipation. Dialectical Anthropology 26: 3-4 (2001). pp. 193-233.

${ }^{21}$ Soares, Devotos da Cor, 109.

${ }^{22}$ Mary Karasch fez trabalho hercúleo de identificação das possíveis origens dos africanos encontrados no Rio de Janeiro no século XIX, cotejando seus etnônimos com fontes de antropólogos e historiadores africanistas. Karasch, $A$ vida dos escravos, apêndice A.

${ }^{23}$ Barth, Fredrik. Grupos étnicos e suas fronteiras. In: Teorias da Etnicidade, eds. Poutignat, Philippe Streiff-Fenart, Jocelyne. São Paulo: Ed. Unesp, 1997. pp. 185-227 [1969]; Carneiro da Cunha, Manuela. Etnicidade: da cultura residual mas irredutível. In: Antropologia do Brasil: mito, história, etnicidade. São Paulo: Brasiliense/USP, 1986. pp. 97-108.

${ }^{24}$ Slenes, Robert W. “Malungu, ngoma vem!": África coberta e descoberta do Brasil. Revista da USP 12. (1991/1992). pp. 48-67.

${ }^{25}$ Slenes, Robert W. Na Senzala, uma Flor: Esperanças e Recordações na Formação da Família Escrava - Brasil Sudeste, século XIX. Rio de Janeiro: Nova Fronteira, 1999. Florentino e Góes investigaram práticas de casamento e constituição de famílias igualmente preocupados com os hábitos africanos; Florentino, Manolo e Góes, José Roberto. A Paz das Senzalas: famílias escravas e tráfico atlântico, Rio de Janeiro, c. 1790 - c. 1850. Rio de Janeiro: Editora Civilização Brasileira, 1997.

${ }^{26}$ Wood, Peter H. Black majority: Negroes in colonial South Carolina from 1670 through the Stono Rebellion. New York: Knopf, 1974; Carney, Judith A. Black Rice: The African Origins of Rice Cultivation in the Americas. Cambridge: Harvard University Press, 2001. ${ }^{27}$ Midlo-Hall, Gwendolyn. Africans in Colonial Louisiana: the development of Afro-Creole culture in the eighteenth century. Baton Rouge: Louisiana State University Press, 1992.

${ }^{28}$ Schuler, Monica. "Alas, Alas, Kongo": a social history of indentured African immigration into Jamaica, 1841-1865. Baltimore: The Johns Hopkins University Press, 1980.

${ }^{29}$ Mattos, Hebe Maria. Os "Mina” em Minas: As “Áfricas” no Brasil e a Pesquisa em História Social da Escravidão. Anais do XX Simpósio Nacional da ANPUH - História: Fronteiras, eds. Nodari, Eunice Pedro, Joana Maria e Iokoi, Zilda M. Gricoli. vol. 2. São Paulo: Humanitas/Anpuh, 1999. pp. 675-679.

${ }^{30}$ Oliveira, Maria Inês Côrtes. Retrouver une Identité: Jeux Sociaux des Africains de Bahia. v.1750-v.1890. Tese de doutorado nouveau régime, Université Paris IV, 1992.

${ }^{31}$ Soares, "Os Mina em Minas"; Soares, "Mina, Angola e Guiné".

${ }^{32}$ Nishida, Mieko. Slavery and Identity: ethnicity, gender and race in Salvador, Brazil, 18081888. Bloomington: Indiana University Press, 2003.

${ }^{33}$ Pena, Eduardo Spiller. "Tengo-Tengo", “os senhores da forja”: ferreiros e quilombolas na África Central e no Centro-Oeste da Minas Colonial. Comunicação apresentada no IX Encontro Estadual de História da ANPUH/SC. Florianópolis, 2002.

${ }^{34}$ Tratado proposto a Manuel da Silva Ferreira pelos seus escravos durante o tempo em que se conservaram levantados. c. 1789 in: Reis, João José e Silva, Eduardo, Negociação e Confli- 
to: a resistência negra no Brasil escravista. São Paulo: Companhia das Letras, 1989. pp. 123-4. ${ }^{35}$ Reis, João José. De olho no canto: trabalho de rua na Bahia na véspera da Abolição. Afro-Ásia 24. (2000). p. 199-242; Reis, João José. A greve negra de 1857. Revista da USP 18 (1993). pp. 6-29.

${ }^{36}$ Karasch, $A$ vida dos escravos.

${ }^{37}$ Velasco e Cruz, Maria Cecília. Tradições negras na formação de um sindicato: sociedade de resistência dos trabalhadores em trapiche e café, Rio de Janeiro, 1905-1930. AfroAsia 24 (2000). pp. 243-290.

${ }^{38}$ Reis, João José. Rebelião Escrava no Brasil: a história do levante dos malês. 1835. Edição revista e ampliada. São Paulo: Companhia das Letras, 2003. A primeira edição é de 1986.

${ }^{39}$ Muitas referências se fazem a africanos entre revoltosos e quilombolas. A discussão de etnia, no entanto, é mais rara. Ver Schwartz, Stuart B. Cantos e quilombos numa conspiração de escravos haussás - Bahia, 1814. In: Liberdade por um Fio: História dos Quilombos no Brasil, eds. Reis, João José e Gomes, Flávio dos Santos. São Paulo: Companhia das Letras, 1996. pp. 373-406; Lovejoy, Paul E. Jihad e escravidão: as origens dos escravos muçulmanos da Bahia. Topói 1 (2000). pp. 11-44; Mamigonian, Beatriz Gallotti. Do que 'o preto mina' é capaz: etnia e resistência entre africanos livres. Afro-Asia 24 (2000). pp. 71-95; e uma inspiradora associação entre festa e resistência: Reis, João José. Tambores e temores: a festa negra na Bahia na primeira metade do século XIX. In: Carnaval e outras $f(r)$ estas: ensaios de história social da cultura. Cunha, Maria Clementina P. (ed). São Paulo: Editora da Unicamp, 2002. pp. 104-114.

${ }^{40}$ Soares, Carlos Eugênio Líbano. Zungú: Rumor de Muitas Vozes. Rio de Janeiro: Arquivo Público do Estado do Rio de Janeiro, 1998. Ver também africanos em Soares, Carlos Eugênio Líbano. A capoeira escrava e outras tradiçôes rebeldes no Rio de Janeiro, 1808-1850. Campinas: Editora da Unicamp/CECULT, 2001 e em Gomes, Flávio dos Santos. Histórias de Quilombolas: mocambos e comunidades de senzalas no Rio de Janeiro - século XIX. Rio de Janeiro: Arquivo Nacional, 1995.

${ }^{41}$ Mello e Souza, Laura. O Diabo e a Terra de Santa Cruz: feitiçaria e religiosidade popular no Brasil Colonial. São Paulo: Companhia das Letras, 1986; Reis, João José Reis. Nas malhas do poder escravista: a invasão do Candomblé do Accú. In: Negociação e Conflito, eds. Reis e Silva, pp. 32-61; Reis, João José. A Morte é uma Festa: Ritos Fúnebres e Revolta Popular no Brasil do Século XIX. São Paulo: Companhia das Letras, 1991; Sidney Chalhoub, Cidade Febril: Cortiços e Epidemias na Corte Imperial. São Paulo: Companhia das Letras, 1996.

${ }^{42}$ Florentino, Manolo. Alforria e etnicidade no Rio de Janeiro oitocentista: Notas de pesquisa. Topói 5 (2002). pp. 9-40; Sweet, James. Manumission in Rio de Janeiro, 17491754: an African perspective. Slavery and Abolition 24:1 (2003). pp. 54-70.

${ }^{43}$ Curtin, Philip (ed.). Africa remembered: narratives by West Africans from the era of the slave trade. Madison: University of Wisconsin Press, 1967; Verger, Pierre. Os libertos: sete caminhos na liberdade de escravos na Bahia do século XIX. São Paulo: Corrupio, 1992.

${ }^{44}$ Law, Robin and Lovejoy, Paul (eds.) The Biography of Mahomah Gardo Baquaqua: his passage from slavery to freedom in Africa and America. Princeton: Marcus Wiener, 2001. 
${ }^{45}$ Xavier, Regina C. L. Tito Camargo de Andrade: religião, escravidão e liberdade na sociedade campineira oitocentista. Tese de doutorado em Históra. Unicamp, 2002; Soares, Mariza. Devotos da Cor, e O escravo que virou rei. Nossa História (dez. 2004). pp. 68-71. ${ }^{46}$ P. Alonso de Sandoval, De Instauranda Aethiopum Salute: El mundo de la Esclavitud Negra en America. Bogotá: 1956; Koelle, Sigismund W. Polyglotta Africana, com introdução de P.E.H. Hair. Graz: Akademische Druck - U. Verlagsanstalt, 1963 [1854]. A grata exceção é a compilação da língua geral da Mina por Antônio da Costa Peixoto, discutida por Sílvia Lara. Não era, porém, um estudo com interesse nos africanos e sim no seu controle; Lara, Sílvia Hunold. Os Minas em Minas: Linguagem, Domínio Senhorial e Etnicidade. Anais do XX Simpósio Nacional da ANPUH - História: Fronteiras, eds. Nodari, Eunice, Pedro, Joana Maria e Iokoi, Zilda M. Gricoli. vol. 2. São Paulo: Humanitas/Anpuh, 1999. pp. 681-688.

${ }^{47}$ Gomez, Michael A. Exchanging our Country Marks: the transformations of African identities in the colonial and antebellum South. Chapel Hill: University of North Carolina Press, 1998.

\section{Resumo}

Este artigo traça os contornos de uma nova área da historiografia brasileira, dedicada ao estudo da diáspora africana no Brasil. Nascida nos debates e pesquisas sobre o tráfico de escravos e a escravidão, a área hoje guarda suas próprias questôes teórico-metodológicas, na busca dos historiadores por apreender a experiência própria dos africanos através do Atlântico e na sociedade escravista brasileira. $\mathrm{O}$ artigo discute as soluções dadas pelos historiadores para o desafio de definir a identidade africana no Brasil e apresenta algumas publicações recentes sobre os temas de trabalho, práticas culturais, resistência, religião e trajetórias individuais na diáspora. Palavras-chave: Diáspora africana; historiografia; tráfico de escravos.

\section{Abstract}

This paper maps the contours of a new field in Brazilian historiography, the one devoted to the study of the African Diaspora in Brazil. Drawing from the research and debates on the slave trade and slavery, the field encompasses now its own theoretical and methodological questions, as historians try to single out the experience of African-born individuals across the middle passage and within Brazilian slave society. The paper discusses how historians have worked around the challenge presented by the problem 
of defining African identity in Brazil, and presents some of the recent published work dealing with labor, cultural practices and resistance, religion and individual biographies in the diaspora.

Key Words: African Diaspora; historiography; slave trade 